\title{
Kemampuan Model Z- Score dan Model Springate dalam Memprediksi Financial Distress BPR Multi Artha Sejahtera
}

\author{
Adi Rizfal Efriadi1 ${ }^{*}$ (Ermalina ${ }^{2)}$ \\ ${ }^{1 *, 2)}$ Fakultas Ekonomi Institut Teknologi dan Bisnis Ahmad Dahlan \\ e-mail: adirizfal2009@yahoo.co.id
}

\begin{abstract}
The purpose of this study was to test the ability of the model or analytical tool used to predict the bankruptcy of the company, namely the Altman's Z-afternoon model and the Springate model of BPR Multi Artha Sejahtera whose license has been revoked by the Financial Services Authority (OJK) through Commissioner Decree Number 16 / KDK.03 / 2016 with company considerations deteriorating. The data used is secondary data, namely the 2012-2015 BPR Multi Artha Sejahtera financial report data obtained from Bank Indonesia reports. The data is then analyzed using the Altman Z-score (Z-Score) and Springate (S-Score) formulas to detect whether or not there are indications of bankruptcy before BPR Multi Artha Sejahtera is actually declared bankrupt. The results of this study concluded that overall, both $\mathrm{Z}$-core and S-Score were able to predict the bankruptcy rate of BPR Multi Artha Sejahtera during 2011 - 2015. In the case of BPR Multi Artha Sejahtera bankruptcy the use of S-Score to predict bankruptcy is more appropriate in predicting bankruptcy.
\end{abstract}

Keywords: Altman model, Springate model, financial distress

\section{PENDAHULUAN}

Secara kuantitas, Bank Perekreditan Rakyat (BPR) di Indonesia mengalami penurunan. Data Bank Indonesia (BI) mencatat, jumlah BPR di Indonesia pada tahun 2008 sebanyak 1.771 BPR, terus mengalami penurunan dari tahun ke tahun sampai dengan tahun 2016 yang jumlahnya 1.637 BPR. Dengan demikian sepanjang kurun waktu 2008-2016 terdapat 134 BPR di Indonesia "tutup". Pengurangan jumlah BPR ini dapat terjadi karena dua kemungkinan, yaitu terjadi merger atau terjadi kebangkrutan (pailit). Salah satu alasan merger juga bisa karena BPR tersebut memiliki kinerja yang tidak bagus yang berpotensi pada keabangkrutan.

Meskipun secara jumlah menurun, namun asset BPR mengalami pertumbuhan. Pada tahun 2016, asset BPR secara nasional Rp 111 triliun, mengalami peningkatan secara linier dari tahun-tahun sebelumnya. Pada tahun 2008 misalnya, asset BPR hanya mencapai Rp 32 tiliun. Peningkatan asset BPR yang berbanding terbalik dengan jumlahnya, disinyalir karena jaringan kantor yang tumbuh pesat. Data Februari 2015 misalnya jaringan kantor BPR sebanyak 4.957 kantor. Setahun kemudian (Februari 2016) menjadi 5.990 kantor.

Pada sisi lain, kinerja BPR secara agrerat tidak menyenangkan. Hal ini bisa dilihat dari nilai Non Performing Loan (NPL) BPR masih berada persyaratan minimal, yaitu 5 persen. Sepanjang tahun 2008 sampai dengan tahun 2016, berdasarkan data BI, nilai NPL BPR rata-rata 6 persen. Pada empat tahun terakhir (2013-2016) NPL BPR terus mengalami penurunan. NPL BPR tahun 2013 sebesar 
4,45\% mengalami penurunan pada tahun 2014 yaitu 4,76\%. Begitu juga dengan tahun 2015 dan tahun 2016 yang mecapai 5,40\% dan 6,54\%.

Menurunnya kinerja BPR tersebut harus diwaspadi. Karena BPR akan mengalami kesulitan keuangan secara terus menerus. Jika hal ini berlangsung dalam waktu lama akan mengakibatkan BPR mengalami kebangkrutan. Yaitu kegagalan perusahaan dalam menjalankan operasional perusahaan yang berakibat pada tidak tercapainya laba yang diinginkan. Menurut Harahap (2013), kebangkrutan perusahaan atau likuiditas perusahaan (penutupan perusahaan) dapat disebabkan baik oleh faktor internal maupun faktor eksternal. Kebangkrutan perusahaan [BPR] menurut Fachrudin (2008) dapat ditandai dengan adanya penurunan kondisi keuangan perusahaan yang terjadi secara berkepanjangan dan terus menenus (financial distress), yaitu ketika perusahaan tidak dapat memenuhi jadwal pembayaran atau kekita proyeksi arus kas mengindikasikan bahwa perusahaan tersebut akan segera tidak dapat memenuhi kewajibannya.

Untuk menghindari terjadi kebangkrutan BPR, selain dengan terus bekerja keras meningkatkan kinerjanya, juga harus dievaluasi terutama pada kinerja keuangan seperti memprediksi kebangkrutan. Prediksi ini penting dilakukan sedini mungkin agar perusahaan dapat terhindar dari kebangkrutan karena dapat diantisipasi. Sebagaimana menurut Mamduh dan Halim (2003), analisis kebangkrutan dilakukan untuk memperoleh peringatan awal kebangkrutan tersebut (tanda-tanda kebangkrutan). Semakin awal ditemukannya indikasi kebangkrutan tersebut, semakin baik bagi pihak manajemen karena pihak manajemen bisa melakukan perbaikanperbaikan.

Diantara metode yang sering digunakan dalam melihat kinerja atau kesehatan perusahaan (termasuk bank) dengan pendekatan rasio keuangan seperti rasio CAR, LDR, ROI, REI, NPL, BOPO dan lain sebagainya. Namun model yang sering digunakan untuk memprediksi kebangkrutasn sebuah perusahaan yang populer adalah model Altman (Z-score) dan Springate. Menurut Munawir (2007), analisis Z-score mengacu pada rasio-rasio keuangan perusahaan. Rasio menggambarkan suatu hubungan atau pertimbangan (mathematical relationship) antara suatu jumlah tertentu dengan jumlah yang lain, dan dengan menggunakan alat analisa berupa ratio ini akan dapat menjelaskan atau memberi gambaran kepada penganalisa tentang baik atau buruknya keadaan atau posisi keuangan suatu perusahaan terutama apabila angka ratio pembanding yang digunakan sebagai standar.

Beberapa penelitian yang menguji tentang model Altman adalah Sopiyah Arini dan Triyonowati (2013), menurutnya model Z-Score Altman dapat diimplementasikan dalam mendeteksi kemungkinan terjadinya kebangkrutan pada perusahaan farmasi yang terdaftar di Bursa Efek Indonesia. Ketepatan model Altman dalam memprediksi kebangkrutan telah dikonfimasi juga oleh Fanny dan Saputra (2005), dengan melakukan penelitian mengenai pengaruh model prediksi kebangkrutan terhadap opini audit going concern. Model prediksi kebangkrutan yang digunakan adalah modelAltman, model Zmijeweski, dan model Springate.

Dari hasil penelitian tersebut, mereka menemukan bahwa model prediksi Altman merupakan model prediksi terbaik diantara ketiga model yang digunakan tersebut dalam mempengaruhi ketepatan 
pemberian opini audit, selanjutnya diikuti oleh model Springate. Sedangkan penggunaan model Zmijewski memberikan performa terburuk dalam memprediksi kebangkrutan. Senada dengan Fanny dan Saputra (2005), menurut Hadi dan Anggraeni (2008), dari ketiga model, yaitu model zmijewski, model altman, dan model springate, model prediksi Altman yang terbaik dalam memprediksi kebangkrutan perusahaan dibandingkan dengan kedua model lainnya.

Seringnya model Z-Score dan springate digunakan dalam memprediksi kebangkrutan perusahaan menarik peneliti untuk menguji model tersebut pada BPR Multi Artha Sejahtera. Sebagaimana diketahui bahwa BPR Multi Artha Sejahtera telah dicabut izinnya oleh Otoritas Jasa Keuangan (OJK) melalui Keputusan Dewan Komisioner Nomor 16/KDK.03/2016 dengan pertimbangan perusahaan yang memburuk. Atas dasar itu penelitian ini akan melihat ketepatan atau kemampuan model Z-Score dan Springate dalam memprediksi kebangkrutan BPR Multi Artha Sejahtera dengan mengunakan data sebelumnya.

Tujuan penelitian ini adalah untuk menguji kemampuan model atau alat analisis yang digunakan untuk memprediksi kebangkrutan perusahaan, yaitu model Altman’s Z-sore dan model Springate.

\section{TINJAUAN PUSTAKA}

\section{Laporan dan Rasio Keuangan}

Kegunaan laporan keuangan dijelaskan oleh Hanafi (2003), yaitu informasi yang dapat dipakai untuk pengambilan keputusan, mulai dari investor atau calon investor sampai dengan manajemen perusahaan itu sendiri. Laporan keuangan akan memberikan informasi mengenai profitabilitas, risiko, timing aliran kas, yang kesemuanya akan mempengaruhi harapan pihak-pihak yang berkepentingan. Baik untuk kepentingan pihak internal maupun pihak eksternal. Dengan demikian laporan keuangan bertujaun untuk, pertama, memberikan informasi yang bermanfaat bagi investor, kreditur, dan pemakai lainnya sekarang atau masa yang akan datang untuk membuat keputusan investasi. Kedua, memberikan informasi yang bermanfaat untuk pemakai eksternal untuk memperkirakan jumlah waktu, dan ketidakpastian dari penerimaan kas dari bunga dan dari penjualan atau utang pinjaman. Ketiga, Memberi informasi untuk menolong infestor, kreditur, dan pemakai lainnya untuk memperkirakan jumlah waktu, dan ketidakpastian aliran kas masuk bersih ke perusahaan.

Tujuan dari analisis rasio keuangan menurut Weston (1995) adalah membantu manajer keuangan memahami apa yang perlu dilakukan perusahaan berdasarkan informasi yang tersedia yang sifatnya terbatas berasal dari laporan keuangan. Analisis rasio keuangan juga dapat mengurangi ketergantungan para pengambil keputusan pada dugaan murni, terkaan, dan intuisi, mengurangi dan mempersempit lingkup ketidakpastian yang tidak bisa diletakkan pada setiap proses pengambilan keputusan. 


\section{Financial Distress}

Financial distress atau kesulitan keuangan dapat diartikan sebagai ketidakmampuan perusahaan untuk membayar kewajiban keuangannya pada saat jatuh tempo yang menyebabkan kebangkrutan perusahaan (Darsono dan Ashari, 2005). Kesulitan keuangan dapat dilihat diantara dua titik yaitu likuiditas (jangka pendek) dan insovabel. Kesulitan keuangan jangka pendek sifatnya sementara namun dapat menjadi kesulitan keuangan yang sangat buruk. Semakin buruk maka suatu perusahaan dapat diprediksikan bangkrut karena mengalami kesulitan keuangan (Putri dan Diyani, 2016). Kebangkrutan sebuah perusahaan disebabkan karena beberapa faktor. Menurut Adnan (2000) kebangkrutan tersebut dapat disebabkan karena faktor umum, faktor internal, dan faktor ekternal (Peter dan Yoseph, 2011).

Faktor umum terdiri dari sektor ekonomi (inflasi dan deflasi), faktor sosial (perubahan gaya hiudp masyarakat), faktor teknologi (biaya teknologi), dan faktor sektor pemerintah (kebijakan pemerintah seperti pencabutan subsidi). Faktor internal perusahaan dapat disebabkan oleh kredit yang diberikan terlalu besar, menajemen tidak efisien karena kurangnya pengalaman dan kemampuan, serta adanya penyalahgunaan wewenang. Sementara faktor eksternal dapat disebabkan oleh faktor konsumen yang tidak loyal, faktor kreditur, dan faktor persaingan.

\section{Model Pengukuran Financial Distress}

\section{Model Altman}

Banyak model analisis yang dikembangan untuk memprediksi kebangkrutan perushaan. Diantara model yang populer adalah model yang kembangkan oleh Altman. Edward I. Altman (1968) adalah salah satu peneliti yang melakukan penelitian berkaitan dengan kasus dan fenomena Kebangkrutan. Untuk memprediksi kebangkrutan perusahaan, Altman menemukan rumus yang disebut Z-Score. Menurut Rudianto (2013), analisis Z-Score adalah metode untuk memprediksi kebangkrutan hidup perusahaan dengan mengkombinasikan beberapa rasio keuangan yang umum dan pemberian bobot yang berbeda satu dengan lainnya. Altman menyeleksi 22 rasio keuangan, dan pada akhirnya menemukan 5 rasio yang dapat dikombinasikan untuk melihat perusahaan yang bangkrut dan tidak bangkrut, 5 jenis rasio tersebut yaitu: Modal Kerja terhadap Total Aset (Working Capital to Total Assets); Laba Ditahan terhadap Total Aset (Retained Earning to Total Assets); EBIT terhadap Total Aset (Earning Before Interest and Taxes to Total Assets); Nilai buku ekuitas terhadap total hutang (Market Value of Equity to Book Value of Total Debt) dan Penjualan terhadap Total Aset (Sales to Total Assets).

Altman (1968) menggunakan metode step-wise multivariate discriminant anlysis (MDA) dalam penelitiannya. Seperti regresi logistik, teknik statistika ini juga biasa digunakan unutk membuat model dimana variabel dependennya merupakan variabel kualitatif. Output dari teknik MDA adalah persamaan linear yang bisa membedakan antara dua keadaan variabel dependen. 
Model Altman di atas, disebut juga dengan model Altman I, mengalami bebagai kelemahan, karena hanya dapat diaplikasikan pada perusahaan manufaktur go public. Kemudian Altman melakukan penelitian pada perusahaan manufaktur non go public dengan mengembangkan model Altman yang baru atau biasa disebut dengan Model Altman Z-score’s Revisi.

Mesipun model Altman tersebut telah mengalami perubahan (revisi), namun kelemahannya tetap pada penggunaan atau penerapatan jenis perusahaan. Model ini hanya mampu meprediksi kebangkrutan perusahaan manufaktur baik yang go public maupun yang tidak. Atas dasar itu Altman kemudian mengembangkan kembali modelnya yang dapat diaplikasikan diberbagai jenis perusahaan, baik manufaktur maupun non manufaktur, baik go public maupun non go public. Formula Z-score terakhir merupakan rumus yang dinilai sangat fleksibel karena dapat digunakan untuk berbagai jenis bidang usaha perusahaan dan cocok digunakan di negara berkembang seperti Indoneisa (Rudianto, 2013), yaitu:

$Z "=6,56 X_{1}+3,26 X_{2}+6,72 X_{3}+1,05 X_{4}$

Dimana :

$\mathrm{X}_{1}=$ Working Capital/Total Asset

$\mathrm{X}_{3}=$ Earning Before Interest And Taxes/Total Asset

$\mathrm{X}_{2}=$ Retained Earnings / Total Asset

$\mathrm{X}_{4}=$ Book Value Of

Tabel 1. Tolak Ukur Analisis Altman Z-score

\begin{tabular}{llll}
\hline $\begin{array}{c}\text { Manufaktur Go } \\
\text { Public }\end{array}$ & $\begin{array}{c}\text { Manufaktur } \\
\text { non-Go Public }\end{array}$ & $\begin{array}{c}\text { Berbagai Jenis } \\
\text { Perusahaan }\end{array}$ \\
\hline $\mathrm{Z}>2,99$ & $\mathrm{Z}>2,90$ & $\mathrm{Z}>2,60$ & $\begin{array}{l}\text { Zona aman (Perusahaan dalam kondisi sehat } \\
\text { sehingga kemungkinan kebangkrutan sangat } \\
\text { kecil terjadi) }\end{array}$ \\
\hline $1,81<\mathrm{Z}<2,99$ & $1,23<\mathrm{Z}<2,90$ & $1,1<\mathrm{Z}<2,60$ & $\begin{array}{l}\text { Zona Abu-abu (Perusahaan dalam kondisi } \\
\text { rawan (grey area). Pada kondisi ini, perusahaan } \\
\text { mengalami masalah keuangan yang harus } \\
\text { ditangani dengan cara yang tepat) }\end{array}$ \\
\hline $\mathrm{Z}<1,81$ & $\mathrm{Z}<1,23$ & $\mathrm{Z}<1,1$ & $\begin{array}{l}\text { Zona berbahaya (Perusahaan dalam kondisi } \\
\text { bangkrut) }\end{array}$ \\
\hline
\end{tabular}

Sumber: Rudianto, 2013

\section{Model Springate}

Gordon L.V. Springate pada tahun 1978 melakukan penelitian dengan mengikuti prosedur yang dikembangkan Altman, Springate mengunakan step -wise multiple discriminate analysis untuk memilih empat dari 19 rasio keuangan yang popular sehingga dapat membedakan perusahaan yang berada dalam zona bangkrut atau zona aman. Springate Score adalah metode untuk memprediksi kebangkrutan dengan mengkombinasikan beberapa rasio keuangan yang umum dengan diberikan bobot yang berbeda satu sama lainnya. Model ini menekankan terhadap profitabilitas sebagai komponen yang paling berpengaruh terhadap kebangkrutan. Rumus Springate Score untuk berbagai jenis perusahaan sebagai berikut (Rudianto, 2013) : 
$S=1,03 X_{1}+3,07 X_{2}+0,66 X_{3}+0,4 X_{4}$

Dimana:

$\mathrm{X}_{1}=$ Working Capital to Total Assets

$\mathrm{X}_{3}=$ Net Profit Before Taxes to Current Liabilities

$\mathrm{X}_{2}=$ Net Before Interest And Taxes to Total $\mathrm{X}_{4}=$ Sales to Total Assets

Assets

Kriteria yang digunakan dalam model Springate adalah jika nilai S-score $>0,862$ maka dapat dikatakan perusahaan tidak berpotensi untuk bangkrut. Namu jika nilai S-score yang didapat $<0,862$ maka perusahaan dikatakan berpotensi mengalami kebangkrutan. Model ini menghasilkan tingkat keakuratan sebesar 92,5\% dengan menggunakan 40 perusahaan yang diuji oleh Springate.

\section{Penelitian Sebelumnya}

Arini dan Triyonowati (2013), melakukan penelitian dengan menggunakan model Altman ZScore. Penelitian ini dilakukan untuk mengetahui tingkat kebangkrutan perusahaan dengan menggunakan model Altman Z-Score pada perusahaan farmasi yang terdaftar di Bursa Efek Indonesia. Hasil penelitian ini menunjukkan bahwa model Z-Score Altman tersebut dapat diimplementasikan dalam mendeteksi kemungkinan terjadinya kebangkrutan pada perusahaan farmasi yang terdaftar di Bursa Efek Indonesia. Model Z-Score Altman tersebut mengelompokkan perusahaan farmasi pada tiga kategori yaitu tidak bangkrut, rawan bangkrut, dan bangkrut.

Peter dan Yoseph (2011) menguji model analsisis kebangkrutan dengan membangidngkan model Altman dengan model Springate pada PT. Indofood Sukes Makmur tbk. tahun 2005-2009. Hasil penelitiannya menunjukkan bahwa terdapat perbedaan hasil status kebangkrutan pada PT. Indofood Sukses Makmur Tbk. Dimana model Altman mampu memprediksi tingkat kebangkrutan perusahaan, sedangkan hasil analisis model Springate tidak mendeteksi adanya kebangkrutan pada periode penelitian.

Willy (2011), Model Altman (Z-Score) dalam penelitiannya menyimpulkan bahwa salah satu model analisis multivariate yang berfungsi untuk memprediksi kebangkrutan perusahaan dengan tingkat ketepatan dan keakuratan yang relatif dapat dipercaya. Model ini memiliki akurasi mencapai 95\% jika menggunakan data 1 tahun sebelum kondisi kebangkrutan. Sementara Santoso (2011), menyimpulkan bahwa model analisis Springate memiliki keakuratan sebesar 92,2 \% dalam mendeteksi kebangkrutan perusahaan.

\section{METODE PENELITIAN}

Penelitian ini dilakukakn terhadap BPR yang telah dinyatakan bangkrut dan dicabut izinnya oleh OJS, yaitu BPR Multi Artha Sejahtera yang berdomisili di kota Bekasi Jawa Barat. Data yang digunakan adalah data sekunder yaitu data laporan keuangan BPR Multi Artha Sejahtera periode 2012 - 2015 yang diperoleh dari laporan Bank Indonesia pada website www.bi.go.id. Data kemudian 
dianlisis dengan menggunakan rumus Altman Z-score dan Springate untuk mendeteksi ada atau tidaknya indikasi kebangkrutan sebelum BPR Multi Artha Sejahtera benar-benar dinyatakan bangkrut.

\section{HASIL DAN PEMBAHASAN}

Bank Perkreditan Rakyat (BPR) Multi Artha Sejahtera merupakan BPR dibawah naungan PT. BPR Multi Artha Mas Sejahterayang beralamat di Revo Town Nomor 78, Pekayon Jaya, Kota Bekasi, Jawa barat. Setelah sekian lama berdiri, PT. BPR Multi Artha Mas Sejahteraberdasarkan Peraturan Bank Indonesia (PBI) Nomor 11/20/PBI/2009 tanggal 4 Juni 2009 tentang Tindak Lanjut Penanganan terhadap Bank Perkreditan Rakyat Dalam Status Pengawasan Khusus, BPR ini kemudian ditetapkan status Dalam Pengawasan Khusus (DPK). Terhitung sejak tanggal 21 Desember 2016, Izin Usaha PT Bank Perkreditan Rakyat Multi Artha Mas Sejahtera dicabut oleh Otoritas Jasa Keuangan (OJK) melalui Keputusan Dewan Komisioner (KDK) Nomor 16/KDK.03/2016 tanggal 21 Desember 2016.

Alasan pencabutan izin ini adalah karena Penyediaan Modal Minimum atau KPMM PT. BPR Multi Artha Mas Sejahterakurang dari 4\% dan rata-rata Cash Ratio dalam 6 bulan terakhir kurang dari 3\% sejak tanggal 26 Agustus 2016. Berdasarkan salinan Peraturan Otoritas Jasa Keuangan Nomor 11/Pojk.03/2016 Tentang Kewajiban Penyediaan Modal Minimum Bank Umum, disebutkan bahwa Bank [termasuk BPR] diwajibkan untuk menyediakan modal minimum sesuai profil risiko. Selain itu, dalam peraturan tersebut juga disebutkan bahwa bank berkewajiban menyediakan modal minimum sesuai profil risiko, Bank wajib membentuk tambahan modal sebagai penyangga (buffer) sesuai kriteria yang diatur dalam Peraturan Otoritas Jasa Keuangan ini. Karena tidak terpenuhi kewajiban tersebut, maka izin PT. BPR Multi Artha Mas Sejahteradicabut.

\section{Laporan Keuangan BPR Multi Artha Sejahtera}

Berdasarkan laporan keuangan PT BPR Multi Artha Sejahtera periode 2011 - 2015, kondisi keuangan PT BPR Multi Artha Sejahtera mengalami penurunan. Beberapa komponen yang menjadi perhatian (concern) dalam penelitian ini adalah modal kerja, total asset, laba ditahan, pendapatan sebelum Bunga dan pajak, nilai ekuitas dan total hutang. Nilai modal kerja PT BPR Multi Artha Sejahtera tahun 2011 sampai dengan tahun 2015 diperoleh dari hasil pengurangan ativa lancar dengan pasiva lancar pada periode yang sama. Sebagai contoh tahun 2011, aktiva lancar PT BPR Multi Artha Sejahtera sebesar Rp 8,6 milyar sedangkan jumlah atau total pasiva lancar sebesar Rp 7,4 milyar sehingga diperolah modal kerja PT BPR Multi Artha Sejahtera tahun 2011 sebesar Rp 1,2 milyar. Begitu juga untuk tahun-tahun berikutnya.

Berdasarkan perhitungan modal kerja PT BPR Multi Artha Sejahtera dari tahun 2011 sampai dengan tahun 2015 mengalami penurunan, meskipun pada tahun 2012 mengalami kenaikan dari tahun sebelumnya, tahun 2011. Namun tahun-tahun setelahnya mengalami penurunan bahkan minus. Hal ini menandakan bahwa total pasiva atau modal dan hutang lancar lebih besar dibandingkan dengan aktiva 
atau harta lancarnya. Sehingga modal kerja mengalami negatif dari tahun 2013 sampai dengan tahun 2015.

Total aset PT BPR Multi Artha Sejahtera secara kesuluruhan sepanjang tahun 2011 sampai tahun 2015 juga mengalami penurunan. Meskipun tahun 2014 mengalami peningkatan dari tahun sebelumnya. Total aset PT BPR Multi Artha Sejahtera pada tahun 2011 sebesar Rp 9,4 milyar mengalami penurunan sampai dengan tahun 2013 menjadi Rp 5,3milyar. Kemudian pada tahun 2014 mengalami kenaikan menjadi Rp 7 milyar dan mengalami penurunan kembali pada tahun 2015 menjadi Rp 5,9milyar. Aset perusahaan merupakan hak yang dapat digunakan dalam operasi perusahaan. Komponen yang dapat dimasukkan ke dalam kolom aset diantaranya adalah gedung atau bangunan atau tanah (asset tetap), baik yang ditempati maupun tidak. Atau dalam bentuk lain seperti penyertaan modal, piutang atau pemberian kredit dan lain-lain.

Pada PT BPR Multi Artha Sejahtera, terhitung tahun 2011 sampai dengan tahun 2015 tidak ditemukan (dalam laporang keuangan) aset tetap seperti tanah atau gedung, kecuali invetaris. Dari total aset PT BPR Multi Artha Sejahtera, hanya terdiri dari kas, pendapatan bunga yang akan diterima, penempatan pada bank lain dan lain sebagainya. Ketiadaan aset tetap inilah, seperti gedung dan tanah, diduga yang dapat menyebabkan terus terjadinya penurunan jumlah aset, karena aset diluar aset tetap sifatnya lebih dapat mengalami fluktuatif dibandingkan dengan aset tetap seperti tanah yang nilainya terus naik.

Sementara laba ditahan PT BPR Multi Artha Sejahtera juga mengalami penurunan. Bahkan dari tahun 2013 sampai dengan tahun 2015 tidak ada (Rp 0). Laba ditahan PT BPR Multi Artha Sejahtera pada tahun 2011 sebesar Rp902 juta mengalami penurunan lebih dari 40 persen pada tahun 2012 sehingga menjadi Rp 371 juta. Dan tahun setelahnya, tahun 2013 sampai dengan tahun 2015 tidak ada laba ditahan. Diantara penyebab menurunnya laba ditahan ini adalah rugi periodik dan pembagian deviden. Kerugian yang terjadi dapat tidak memberikan laba pada perusahaan dan tentu saja tidak akan ada laba yang ditahan. Atau selain mengalami kerugiaan usaha, menurun atau tidak adanya laba ditahan dapat disebabkan oleh adanya pembangian deviden atau keuntungan laba secara keseluruhan, sehingga tidak ada laba yang disisihkan untuk modal.

Penurunan atau tidak adanya laba ditahan akibat dari terjadinya kerugian perusahaan dapat terkonfirmasi dari jumlah pendapatan (sebelum bunga dan pajak) yang selalu menurun bahkan tidak ada. Pendapatan sebelum bunga dan pajak PT BPR Multi Artha Sejahtera pada tahun 2011 sebesar Rp 681 juta tidak mengalami perubahan pada tahun berikutnya yaitu tahun 2012 sebesar Rp 681 juta. Namun pada tahun 2013 sampai dengan tahun 2015 menunjukkan tidak adanya pendapatan atau Rp 0. Hal ini telah menimbulkan tidak adanya laba perusahaan termasuk laba ditahan.

Penurunan keuangan PT BPR Multi Artha Sejahtera juga ditunjukkan oleh nilai ekuitas. Nilai ekuitas PT BPR Multi Artha Sejahtera pada tahun 2011 sebesar Rp 6,8 milyar; meskipun mengalami peningkatan pada tahun 2012 menjadi sebesar Rp 7,4 milyar namun tahun-tahun berikutnya 
mengalami penurunan. Pada tahun 2013 sebesar Rp 3,8milyar, pada tahun 2014 sebesar Rp 3,6milyar dan pada tahun 2015 sebesar Rp 2,7milyar.

Meskipun pada komponen lainnya mengalami penurunan (negatif) namun tidak pada total hutang yang mengalami penurunan (positif). Jumlah atau total hutang PT BPR Multi Artha Sejahtera pada tahun 2011sebesar RP 9,4milyar mengalami penurunan (posiitf) pada tahun 2012 sehingga menjadi Rp 8,8milyar. Pada tahun 2013 juga mengalami penurunan yang cukup signifikan sehingga menjadi Rp 1,5milyar. Namun pada tahun berikutnya yaitu pada tahun 2014 kembali mengalami kenaikan menjadi Rp 3,3milyar dan Rp 3,2milyar pada tahun 2015.

Tabel 1. Laporan Keuangan PT BPR Multi Artha Sejahtera Periode 2011 - 2015 (dalam ribuan)

\begin{tabular}{llllll}
\hline & $\mathbf{2 0 1 1}$ & $\mathbf{2 0 1 2}$ & $\mathbf{2 0 1 3}$ & $\mathbf{2 0 1 4}$ & $\mathbf{2 0 1 5}$ \\
\hline Modal Kerja & $1,248,483$ & $1,946,137$ & $-1,412,579$ & $-3,321,561$ & $-3,187,540$ \\
Total Aset & $9,482,818$ & $8,894,751$ & $5,387,541$ & $7,023,161$ & $5,987,543$ \\
Laba ditahan & 902,664 & 371,356 & 0 & 0 & 0 \\
Pend. Sblm bunga \& pajak & 681,157 & 681,157 & 0 & 0 & 0 \\
Nilai buku ekuitas & $6,871,355$ & $7,467,368$ & $3,856,759$ & $3,642,932$ & $2,755,692$ \\
Total Hutang & $9,482,818$ & $8,894,751$ & $1,530,782$ & $3,380,229$ & $3,231,851$ \\
\hline
\end{tabular}

Sumber: Bank Indonesia 2017, data diolah

\section{Memprediksi Kebangkrutan dengan Pendekatan Z-Score}

Mengacu pada pembahasan sebelumnya, tentang (laporan) keuangan PT BPR Multi Artha Sejahtera, berikut akan diprediksi kebangkrutannya pada tahun-tahun sebelumnya, yaitu tahun 2011 sampai degnan tahun 2015 sebelum terjadi likuidasi. Alat untuk meprediksi kebangkrutan yang pertama adalah dengan menggunakan rumus Altman atau Z-Score.

Dari hasil perhitungan dengan menggunakan rumus Z-Score diketahui $\mathrm{X}_{1}$ sampai dengan $\mathrm{X}_{4}$ sebagaimana terdapat dalam Tabel 2 sebagai berikut:

Tabel 2 Hasil Prediksi Kebangkrutan PT BPR Multi Artha Sejahtera Dengan menggunakan rumus Z-Score

\begin{tabular}{llllll}
\hline & $\mathbf{2 0 1 1}$ & $\mathbf{2 0 1 2}$ & $\mathbf{2 0 1 3}$ & $\mathbf{2 0 1 4}$ & $\mathbf{2 0 1 5}$ \\
\hline $\mathbf{X}_{\mathbf{1}}$ & 0,131657 & 0,218796 & $-0,26219$ & $-0,47294$ & $-0,53236$ \\
$\mathbf{X}_{\mathbf{2}}$ & 0,095189 & 0,04175 & 0 & 0 & 0 \\
$\mathbf{X}_{\mathbf{3}}$ & 0,071831 & 0,07658 & 0 & 0 & 0 \\
$\mathbf{X}_{\mathbf{4}}$ & 0,724611 & 0,839525 & 2,51947 & 1,077718 & 0,852667 \\
$\mathbf{Z}$-score & $\mathbf{2 , 4 1 7 5 3 4}$ & $\mathbf{2 , 9 6 7 5 2 4}$ & $\mathbf{0 , 9 2 5 4 5 3}$ & $\mathbf{- 1 , 9 7 0 9 1}$ & $\mathbf{- 2 , 5 9 6 9 9}$ \\
\hline
\end{tabular}

Sumber: Bank Indonesia, 2017, data diolah

Dari hasil perhitungan dengan rumus Z-Score sebagaimana dalam Tabel 2 di atas, maka diinterpretasikan atau disimpulkan sebagai berikut: 
Tabel 3. Hasil Intrepretasi Prediksi Kebangkrutan dengan Pendekatan Z-Score

\begin{tabular}{lll}
\hline Tahun & Z-Score ) Indeks Z” & Keterangan \\
\hline 2011 & 2,417534 & Grey area \\
2012 & 2,967524 & Diprediksi tidak bangkrut (sehat) \\
2013 & 0,925453 & Diprediksi bangkrut \\
2014 & $-1,97091$ & Diprediksi bangkrut \\
2015 & $-2,59699$ & Diprediksi bangkrut \\
\hline
\end{tabular}

Sumber: data diolah 2017

Berdasarkan hasil perhitungan untuk mendeteksi kebangkrutan PT BPR Multi Artha Sejahtera pada tahun 2011 sampai dengan tahun 2015 dengan menggunakan rumus Altman atau Z-Score, sebagaimana Tabel 4.2 dan Tabel 4.3 diketahui bahwa pada tahun 2011 keuangan PT BPR Multi Artha Sejahtera berada pada grey area karena memiliki indeks Z” sebesar 2,4 atau pada kondisi kritis dan mendekati kebangkrutan, namun belum mengalami kebangkrutan. Pada kondisi ini juga dapat diketahui gejala akan terjadinya kebangkrutan. Gejala ini kemudian dapat diatasi pada tahun berikutnya sehingga indeks Z” meningkat menjadi 2,9. Namun pada tahun berikutnya dari tahun 2013 sampai dengan tahun 2015, kembali turun dengan indeks Z” di bawah 2,6. Sehingga statusnya berubah menjadi diprediksi mengalami kebangkrutan. Tingkat prediksi kebangkrutan dengan pendekatan ZScore juga dapat dilihat pada Gambar 1 sebagai berikut:

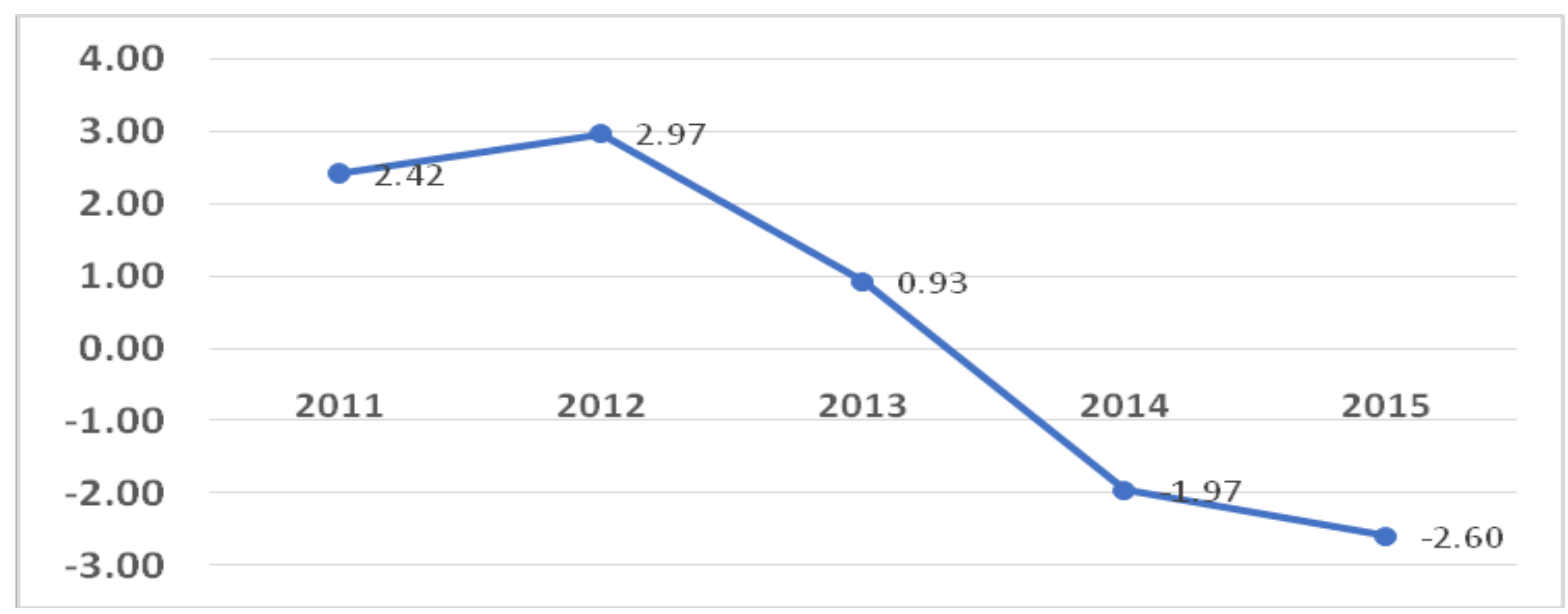

Gambar 1. Z-Score (Indeks Z”) PT BPR Multi Artha Sejahtera 2011 - 2015 Sumber: data diolah, 2017

\section{Memprediksi Kebangkrutan dengan Pendekatan S-Score}

Prediksi kebangkarutan selanjutnya atas PT BPR Multi Artha Sejahtera antara tahun 2011 sampai dengan tahun 2015 dilakukan dengan pendekatan Springate atau S-Score. Adapun rumus yang digunakan adalah sebagai berikut:

Hasil perhitungan prediksi kebangkrutan dengan menggunakan rumus S-Score dapat dilihat pada Tabel 4 sebagai berikut: 
Tabel 4. Hasil Prediksi Kebangkrutan PT BPR Multi Artha Sejahtera dengan menggunakan rumus S-Score

\begin{tabular}{llllll}
\hline & $\mathbf{2 0 1 1}$ & $\mathbf{2 0 1 2}$ & $\mathbf{2 0 1 3}$ & $\mathbf{2 0 1 4}$ & $\mathbf{2 0 1 5}$ \\
\hline $\mathbf{X}_{\mathbf{1}}$ & 0,131657 & 0,218796 & $-0,26219$ & $-0,47294$ & $-0,53236$ \\
$\mathbf{X}_{\mathbf{2}}$ & 0,071831 & 0,07658 & 0 & 0 & 0 \\
$\mathbf{X}_{3}$ & 0,071831 & 0,07658 & 0 & 0 & 0 \\
$\mathbf{X}_{\mathbf{4}}$ & 0 & 0 & 0 & 0 & 0 \\
\hline S-score & $\mathbf{0 , 4 0 3 6 7 9}$ & $\mathbf{0 , 5 1 1 0 0 2}$ & $\mathbf{- 0 , 2 7 0 0 6}$ & $\mathbf{- 0 , 4 8 7 1 3}$ & $\mathbf{- 0 , 5 4 8 3 3}$ \\
\hline
\end{tabular}

Sumber: data diolah, 2017

Data di atas menujukkan skor atau indeks tingkat kebangrutan PT BPR Multi Artha Sejahtera periode 2011 - 2015 dengan menggunakan rumus S-Score. Berdasarkan data di atas skor untuk menilai kebangkrutan setiap tahun berada di bawah 0,8. Tahun 2011 nilai S-Score sebesar 0,403679, pada tahun 2012 sebesar 0,511002. Bahkan tahun 2013 sampai dengan tahun 2015 negatif, yaitu masing-masing -0,27006, -0,48713, dan -0,54833. Hal ini dapat disimpulkan bahwa berdasarkan rumus Springate atau S-Score. Setiap tahun (2011 - 2015) PT BPR Multi Artha Sejahtera dapat diprediksi kebangkrutannya. Beriktu adalah intrepretasi atau kesimpulan tingkat kebangkrutan PT BPR Multi Artha Sejahteraperiode 2011 - 2015 dengan pendekatan rumus S-Score:

Tabel 5. Hasil Intrepretasi Prediksi Kebangkrutan dengan Pendekatan S-Score

\begin{tabular}{lll}
\hline Tahun & S-Score & Keterangan \\
\hline 2011 & 0,403679 & Berpotensi bangkrut \\
2012 & 0,511002 & Berpotensi bangkrut \\
2013 & $-0,27006$ & Berpotensi bangkrut \\
2014 & $-0,48713$ & Berpotensi bangkrut \\
2015 & $-0,54833$ & Berpotensi bangkrut \\
\hline
\end{tabular}

Sumber: data diolah 2017

Untuk memperjelas tingkat prediksi kebangkrutan PT BPR Multi Artha Sejahtera periode 2011 2015dengan pendekatan S-Score juga dapat dilihat pada Gambar 2 sebagai berikut:

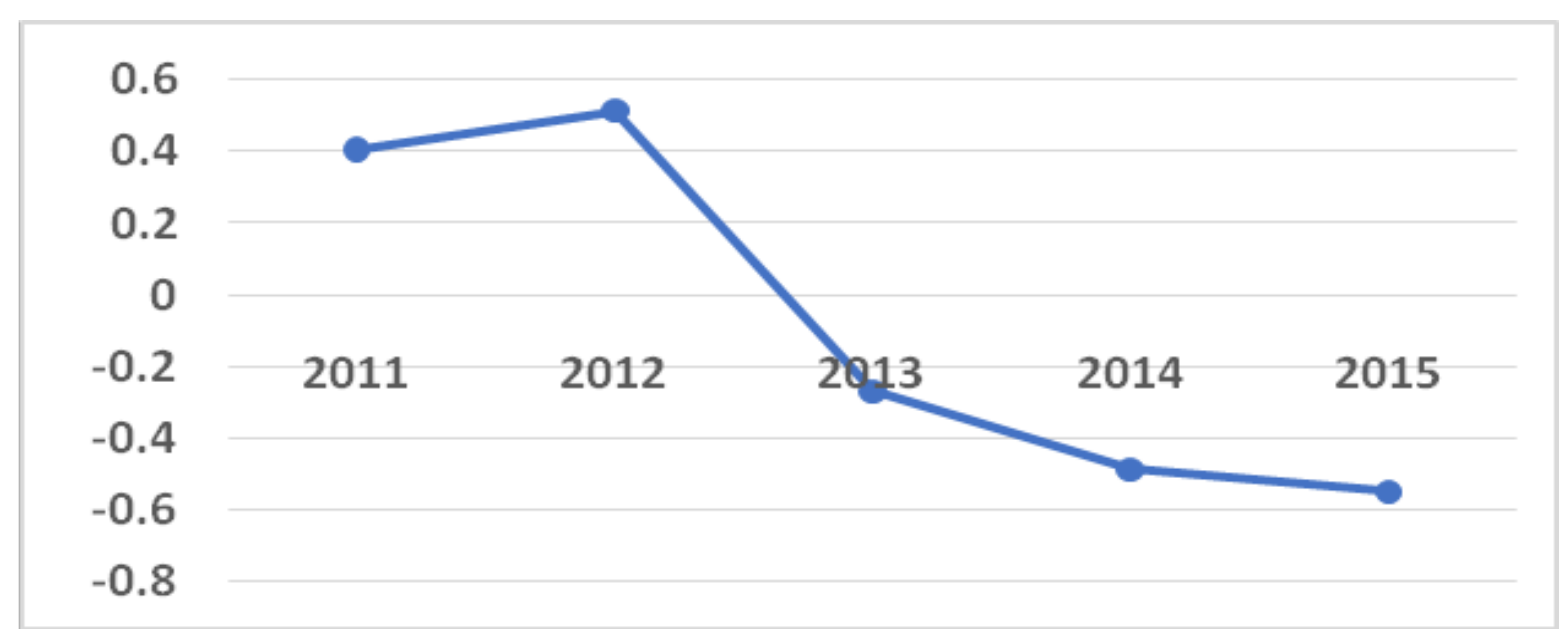

Gambar 2. S-Score (Indeks S”) PT BPR Multi Artha Sejahtera 2011 - 2015

Sumber: data diolah, 2017 


\section{KESIMPULAN DAN IMPLIKASI}

Dari hasil penelitian sebagaimana telah diuraikan pada bab sebelumnya, penelitian ini menyimpulkan bahwa:

1. Secara keseluruhan, baik Z-core maupun S-Score mampu untuk memprediksi tingkat kebangrutan BPR Multi Artha Sejahtera pada tahun 2011 - 2015;

2. Pada kasus kebangrutan BPR Multi Artha Sejahtera penggunaan S-Score untuk memprediksi kebangkrutan lebih tepat dalam memprediksi kebangkrutan.

Implikasi dari penelitian ini adalah prediksi kebangkrutan dengan pendekatan Z-Score mapun dengan pendekatan S-Score dapat atau mampu memprediksi kebangkrutan sebuah perusahaan khsusunya perbankan. Oleh karena perusahaan-perusahaan dapat menggunakan kedua pendekatan ini dalam memprediksi kebangkrutan perusahaannya untuk mencegah terjandinya kebangkrutan pada masa yang akan datang.

\section{REFERENSI}

Arini dan Triyonowati, 2013. Analisis Altman Z-Score Untuk Memprediksi Kebangkrutan Pada Perusahaan Farmasi Di Indonesia. Jurnal Ilmu \& Riset Manajemen. Vol. 2. No. 11 Hal. 1-17

Fachrudin, K.,A. 2008. Kesulitan Keuangan Perusahaan dan Personal. Medan: USU Press

Fanny, M., dan Saputra, S. 2005. Opini Audit Going Concern : Kajian Berdasarkan Model Prediksi Kebangkrutan, Pertumbuhan Perusahaan, Dan Reputasi Kantor Akuntan Publik (Studi Pada Emiten Bursa Efek Jakarta). Simposium Nasional Akuntansi VIII. 966-978.

Hadi, S, dan Anggraeni, A, 2008. Pemilihan Prediktor Delisting Terbaik (Perbandingan Antara The Zmijewski Model, The Altman Model, dan The Springate Model). Skripsi. Fakultas Ekonomi. Universitas Islam Indonesia. Yogyakarta

Harahap, S., S. 2013. Analisis Kritis atas Laporan Keuangan. Jakarta: Raja Grafindo Persada Harjito, D. A. \& Marton0, 2012. Manajemen Keuangan Edisi Kedua. Yogyakarta: EKONISIA

Mamduh, M., H., dan Halim, A., 2009. Analisis Laporan Keuangan. Yogyakarta: UPP AMP YKPN.

Peter dan Yoseph, 2011. Analisis Kebangkrutan dengan Metode Z-score Altman, Springate dan Zmijewski pada PT. Indofood Sukses Makmur tbk Periode 2005 - 2009. Akurat Jurnal Ilmiah Akuntansi. Vol.2 Nomor 04

Putri, N., I., dan Diyani, L., A., 2016. Analisis Rasio Keuangan dan Metode Z-Score untuk Menilai Kinerja Keuangan serta Memprediksi Kebangkrutan pada PT. Herba Medica Indonesia Tahun 2010-2012. Kalbisocio,Volume 1 No. 1, Hal. 1-11

Rudianto. 2013. Akuntansi Manajemen Informasi untuk Pengambilan Keputusan Strategis. Jakarta: Erlangga

Sopiyah, A., dan Triyonowati. 2013. Analisis Altman Z-Score Untuk Memprediksi Kebangkrutan Pada Perusahaan Farmasi Di Indonesia. Jurnal Ilmu \& Riset Manajemen. Vol. 2. No. 11. Hal. $1-17$ 